Vol. 24, No. 3, Juli 2021, hlm. 507-520

p-ISSN: 1410-9344; e-ISSN: 2549-5631

WARTA LPM

homepage: http://journals.ums.ac.id/index.php/warta

\title{
Implementasi Pembelajaran Multiliterasi Berbasis Engaged Learning dalam Pelatihan Pengembangan Media Pembelajaran
}

\author{
${ }^{1}$ Arti Prihatini, ${ }^{2}$ Sugiarti \\ ${ }^{1,2}$ Universitas Muhammadiyah Malang

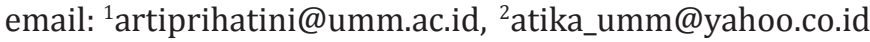

\section{Article Info}

Submitted: 19 January 2021

Revised: 19 May 2021

Accepted: 24 June 2021

Published: 20 July 2021

Keywords: learning media, multiliteracy learning, engaged learning

\begin{abstract}
Multiliteracy learning is important because it integrates various learning resources in order to improve aspects of thought, feeling, and intrinsic motivation (engaged learning). Based on observations and interviews at SMP Aisyiyah Boarding School Malang, literacy activities have been carried out by the students' reading activity before learning, but have not utilized learning media that support the development of students' multiliteracy skills and have not integrated intrinsic motivation with aspects of students' thought and feeling. Based on this, we held training on the development of multiliteracy learning media based on engaged learning, namely a learning model that integrated students' cognitive, emotional, and intrinsic motivation. The method was carried out in four activities, namely the preparation, incubation, illumination, and verification stages, six online meetings for two months accompanied by intensive consultation with 12 teachers of SMP Aisyiyah Boarding School Malang. The instruments used were pretest and posttest sheets, as well as interview guides. The activity was declared successful if $75 \%$ of the participants got a minimum posttest score of 75 . The results showed that there was an increase of $14 \%$ from pretest to posttest. In the pretest, only $25 \%$ had a minimum score of 75 , but in the posttest it increased to $100 \%$. Gradually, more and more teachers were carried out activities very well starting from the preparation, incubation, illumination, to verification stages so the teachers could produce 10-20 minute learning videos, as well as lesson plans. Multiliteracy learning was implemented by utilizing various learning resources and stimulation of critical literacy. Engaged learning was implemented through the use of learning methods and the development of activities that integrated aspects of thought, feeling, and intrinsic motivation. The learning videos produced by the teachers have been uploaded on their respective YouTube channels and used in online learning practices.
\end{abstract}


Kata kunci: media pembelajaran, pembelajaran multiliterasi, engaged learning

\section{Abstrak}

Pembelajaran multiliterasi penting dilakukan karena mengintegrasikan beragam sumber belajar sehingga mampu meningkatkan aspek pikiran, perasaan, dan motivasi intrinsik (engaged learning). Berdasarkan observasi dan wawancara di SMP Aisyiyah Boarding School Malang, kegiatanliterasitelah dilaksanakan dengan membaca bebas dan mandiri bagi siswa sebelum pembelajaran dimulai, tetapi belum memanfaatkan media pembelajaran yang mendukung pengembangan keterampilan multiliterasi siswa dan belum mengintegrasikan motivasi intrinsik dengan aspek pikiran dan perasaan siswa. Berdasarkan hal itu, tim pelaksana mengadakan pelatihan pengembangan media pembelajaran multiliterasi berbasis engaged learning, yakni model pembelajaran yang mengintegrasikan aspek kognitif, emosional, dan motivasi intrinsik siswa. Metode dilakukan dalam empat kegiatan, yaitu tahap preparasi, inkubasi, iluminasi, dan verifikasi sebanyak enam kali pertemuan daring selama dua bulan disertai konsultasi intensif dengan mitra 12 guru SMP Aisyiyah Boarding School Malang. Instrumen yang digunakan adalah lembar pretest dan postest, serta panduan wawancara. Kegiatan dinyatakan berhasil jika $75 \%$ peserta mendapatkan skor postest minimal 75. Hasil menunjukkan bahwa terjadi peningkatan $14 \%$ dari pretest ke postest. Pada pretes, hanya $25 \%$ yang skornya minimal 75 , tetapi pada postest meningkat menjadi $100 \%$. Secara bertahap, semakin banyak guru yang melaksanakan kegiatan dengan Sangat Baik (SB) mulai dari tahap preparasi, inkubasi, iluminasi, hingga verifikasi sehingga menghasilkan video pembelajaran berdurasi 10-20 menit, serta RPP. Pembelajaran multiliterasi diimplementasikan dengan memanfaatkan beragam sumber belajar dan stimulasi literasi kritis. Engaged learning diimplementasikan melalui pemanfaatan metode pembelajaran dan pengembangan aktivitas yang mengintegrasikan aspek pikiran, perasaan, dan motivasi intrinsik. Video pembelajaran yang dihasilkan para guru telah diunggah di channel Youtube masingmasing dan dimanfaatkan dalam praktik pembelajaran daring.

\section{PENDAHULUAN}

Kompetensi multiliterasi merupakan kondisi ketika seseorang memiliki kemampuan memanfaatkan beragam bentuk informasi secara bijaksana dan cerdas. Akan tetapi, berdasarkan hasil studi PISA 2018, kompetensi multiliterasi siswa Indonesia masih tergolong rendah sebab Indonesia menempati level 1 (terendah) dari 6 level (tertinggi). Kompetensi multiliterasi tersebut mencakup literasi membaca, literasi matematika, dan literasi sains (Ramdhani et al., 2021).

Berdasarkan observasi dan wawancara yang dilakukan di SMP Aisyiyah Boarding School Malang, diperoleh informasi bahwa persoalan media yang digunakan dalam pembelajaran masih sederhana sehingga belum memberikan pemahaman secara komprehensif dengan memanfaatkan berbagai sumber informasi. Padahal, media sangat diperlukan sebagai pendukung guru dalam memberikan penjelasan materi baik yang bersifat konkret maupun abstrak(Cahyani, 2018). Akan tetapi, penggunaan media ini diperlukan suatu keterampilan dan kekreatifan yang dituntut pada seorang guru sehingga siswa terasa berminat dan tertarik untuk mengikuti pelajaran.

Pada dunia pendidikan, big data ini bisa dimanfaatkan untuk inovasi pembelajaran. Big data dapat berkontribusi terhadap praktik pembelajaran, seperti meningkatkan pengalaman siswa untuk mengembangkan 
prestasi akademiknya, meningkatkan pengambilan keputusan secara efektif berdasarkan fakta yang ada, dan memberikan respon strategis terhadap perubahan global (Daniel, 2015). Guru dapat memperkaya materi dan sumber belajar, memanfaatkan beragam aplikasi sebagai media pembelajaran, mengakses model pembelajaran terbaru untuk diterapkan di kelas, bahkan memanfaatkan beragam informasi untuk mengembangkan perangkat pembelajaran. Di sisi lain, para siswa juga dapat mengembangkan kompetensinya karena siswa dapat belajar mandiri dengan memanfaatkan teknologi dan informasi yang saat ini dapat dengan mudah diakses. Media pembelajaran merupakan alat atau perlengkapan yang dapat digunakan pendidik untuk menyampaikan pesan (materi) untuk siswa sehingga mendukung terlaksananya kegiatan pembelajaran (Widodo \& Wahyudin, 2018). Melalui media inilah, siswa memperoleh pengetahuan yang bersifat konkret. Selanjutnya media yang digunakan dalam pembelajaran memudahkan siswa untuk memahami konsep yang abstrak menjadi lebih mudah. Sebagaimana penelitian sebelumnya yang juga mengemukakan bahwa penggunaan media yang tepat dapat mendukung guru dalam melaksanakan pembelajaran sehingga siswa dapat memahami materi yang awalnya abstrak menjadi lebih konkret (Muhson, 2010)

Untuk mendapatkan manfaat secara optimal dari era big data ini, dibutuhkan kompetensi multiliterasi dalam diri siswa. Kompetensi multiliterasi merupakan kondisi ketika seseorang memiliki kemampuan memanfaatkan beragam bentuk informasi secara bijaksana dan cerdas. Sebagaimana penelitian terdahulu yang menemukan bahwa pembelajaran yang dilaksanakan berdasarkan pedagogi multiliterasi dan pemanfaatan teknologi dapat memfasilitasi pengalaman belajar yang bermakna bagi siswa dan membantu siswa mencapai kemampuan multiliterasinya (Cooper et al., 2013). Misalnya, siswa memanfaatkan film sebagai media untuk mempelajari unsur intrinsik karya sastra, siswa mencermati video cerita perjalanan untuk mengembangkan literasi spasial, siswa bermain game asah otak untuk meningkatkan literasi numerik, dan sebagainya.
Sementara itu, media perlu dikembangkan agar memiliki daya guna tinggi untuk menopang proses pembelajaran berbasis multiliterasi. Pembelajaran berbasis multiliterasi berorientasi pada pembelajaran active citizenship, terfokus pada siswa sebagai subjek dalam proses perkembangan pengetahuannya, memfasilitasi siswa untuk berkontribusi dan bernegosiasi dengan orang, dan komunitas lain untuk kepentingan bersama. Tujuannya adalah membentuk suasana pembelajaran yang produktif, relevan, inovatif, kreatif, dan emansipatif (Cope \& Kalantzis, 2013). Berkaitan dengan era big data, media pembelajaran juga perlu memanfaatkan berbagai jenis media yang telah berkembang pesat dan membantu siswa memahami dan memanfaatkan informasi yang tersedia dari berbagai sumber, seperti website dan media sosial (Mirra et al., 2018). Sekolah sebagai lembaga pendidikan hendaknya berkepentingan untuk mewujudkan hal tersebut dengan memanfaatkan kemudahan akses informasi pada era industri $4.0 \mathrm{ini}$.

Berkaitan dengan hal tersebut, seorang guru harus mampu memanfaatkan berbagai sumber informasi untuk pengembangan media dalam menjawab kebutuhan pembelajaran untuk mengembangkan aspek multiliterasi. Perkembangan teknologi dan informasi berpengaruh pada tersedianya data yang memadai tentang berbagai informasi yang relevan dengan topik pembelajaran. Hal ini sejalan dengan pemikiran Wahyudin et al. (2020) tentang "Pengaruh Multiliterasi terhadap Perkembangan Minat Menulis di Kalangan Mahasiswa". Hasil penelitian menunjukkan bahwa pengaruh multiliterasi terhadap perkembangan menulis mahasiswa menunjukkan bahwa mahasiswa yang tertarik dalam menulis bergenre puisi sebanyak $60 \%$, cerpen sebanyak $30 \%$, dan novel sebanyak $10 \%$. Dengan demikian pengaruh model pembelajaran multiliterasi ini sangat berpengaruh terhadap perkembangan menulis di kalangan mahasiswa. Ternyata model literasi memiliki pengaruh positif siswa untuk mengembangkan potensi diri secara maksimal. Ruang ekspresi siswa/ mahasiswa dapat terasah dengan baik karena kemampuan multiliterasi yang dilakukan. 
Oleh karenaitu, guru perlu mengembangkan perangkatpembelajaranyangdapatmemfasilitasi peningkatkan kompetensi multiliterasi siswa. Hal ini diperkuat dengan penelitian Susilo \& Garnisya (2018) tentang "Penerapan Model Multiliterasi untuk Meningkatkan Kemampuan Membaca Pemahaman Siswa Sekolah Dasar" menegaskan bahwa penerapan model multiliterasi dapat meningkatkan kemampuan siswa dalam membaca pemahaman dari siklus 1 sampai dengan siklus 3. Di sisi lain, Al Mubarok (2019) dalam penelitiannya "Pengembangan Media Pembelajaran Macromedia Flash Berbasis Web pada Materi Bangun Ruang Sisi Lengkung Kelas IX SMP 1 Brangsong" mengungkapkan bahwa media pembelajaran macromedia flash berbasis web yang dikembangkan dinyatakan valid untuk digunakan dalam pembelajaran. Dalam konteks ini, guru diharapkan mampu mengembangkan media pembelajaran berbasis multiliterasi. Melalui media pembelajaran diharapkan dapat meningkatkan minat dan motivasi siswa untuk mengikuti pembelajaran dan untuk mengembangkan kompetensinya. Dengan demikian, perlu dilakukan pelatihan pengembanganmediapembelajaranyangmampu memfasilitasi pengembangan keterampilan multiliterasi siswa dengan memanfaatkan model pembelajaran yang mendukung pencapaian kompetensi secara utuh dan terintegrasi.

Berdasarkan uraian tersebut, telah dilaksanakan penelusuran penelitian terdahulu untuk mendalami lebih lanjut tentang pelatihan yang dilaksanakan. Penelitian terdahulu tentang multiliterasi menemukan bahwa kompetensi multiliterasi yang dapat dikembangkan adalah kompetensi linguistik, gestural, visual, audiovisual, dan spasial yang terjadi dalam situasi praktik, pembelajaran terbuka, refleksi pemikiran kritis, dan praktik transformatif pada perkuliahan Pendidikan Bahasa dan Sastra Indonesia (Sari et al., 2013). Pembelajaran multiliterasi juga mampu membantu proses pengembangan keterampilan berpikir kritis siswa dan memfasilitasi proses pembelajaran pada jenjang sekolah dasar (Dafit et al., 2018). Selain itu, model multiliterasi digital lebih efektif dibandingkan dengan model kreatif-produktif dalam pembelajaran menulis teks cerita fantasi pada peserta didik kelas VII SMP (Rifai
\& Setyaningsih, 2019). Berdasarkan temuan penelitian tersebut, dapat dikemukakan bahwa pada setiap jenjang pendidikan pembelajaran multiliterasi memiliki efek yang positif bagi siswa untuk mendapatkan kompetensi yang diharapkan. Akan tetapi, masih terdapat kesenjangan penelitian yang mengintegrasikan pembelajaran multiliterasi berbasis multimedia dan model pembelajaran yang tidak hanya mewadahi perkembangan kognitif, tetapi juga emosional dan motivasi intrinsik. Oleh karena itu, perlu adanya kegiatan pelatihan lanjutan, misalnya pengembangan media pembelajaran berbasis multimedia yang dapat diakses dengan Smartphone (Supriyono et al., 2015) dan disesuaikan dengan kebutuhan pembelajaran) (Kusumaningtyas et al., 2020).

Oleh karena itu, perlu adanya pelatihan terstruktur bagi guru untuk mengembangkan media pembelajaran multiliterasi dengan memanfaatkan engaged learning. Hal itu disebabkan oleh kelebihan engaged learning yang dapat menjadi landasan yang kuat bagi siswa dalam mengembangkan keterampilan dan mengorganisasikan kemampuannya (Dean \& Wright, 2017). Dengan engaged learning, siswa berperan aktif dalam pembelajaran, sedangkan guru berperan sebagai fasilitator dengan memanfaatkan teknologi untuk memfasilitasi proses kontruksi pengetahuan (Banna et al., 2015). Dengan demikian, diharapkan terjadi perkembangan yang terintegrasi antara pikiran (mind), perasaan (heart), dan motivasi intrinsik (flow) (Van De Weghe, 2009). Meskipun pembelajaran saat ini dilakukan secara daring, engaged learning tetap dapat dimanfaatkan karena engaged learning tidak terbatas pada praktik pembelajaran tertentu yang berbentuk pembelajaran di kelas, pelatihan, atau praktikum, tetapi justru dapat diterapkan dalam berbagai konteks pembelajaran pada berbagai topik dan bidang keilmuan (Banna et al., 2015). Dengan harapan bahwa siswa yang berhasil dalam engaged learning tidak hanya dilihat dari hasil pembelajarannya saja, tetapi juga dari proses pembelajarannya sebagai satu kesatuan hubungan yang berkesinambungan berdasarkan sinergi antara motivasi dan pembelajaran aktif (Barkley, 2010). 
Tujuan kegiatan ini adalah meningkatkan kompetensi guru dalam mengembangkan media pembelajaran yang tidak hanya mampu memfasilitasi perkembangan kompetensi multiliterasi siswa, tetapi juga mengintegrasikan kompetensi siswa dalam aspek pikiran, perasaan, dan motivasi intrinsik. Selain itu, hasil dari pengembangan media tersebut juga diharapkan dapat memberikan manfaat pada para siswa agar dapat mengembangkan kompetensi multiliterasi di tengah gelombang informasi yang serba cepat dan serba ada ini secara lebih bijak dan cerdas sehingga hal itu dapat mendukung peningkatan aspek pikiran (kognitif), perasaan (afektif), dan motivasi intrinsiknya.

\section{METODE}

Metode yang digunakan dalam kegiatan ini terdiri atas empat tahap, yaitu tahap preparasi, tahap inkubasi, tahap iluminasi, dan tahap verifikasi. Peserta kegiatan berjumlah 12 orang guru dari SMP Aisyiyah Boarding School Malang. Para guru berasal dari berbagai mata pelajaran sehingga diperoleh berbagai variasi yang berbeda sesuai dengan mata pelajaran yang diampu. Kegiatan pelatihan dilaksanakan sebanyak enam kali pertemuan secara daring disertai konsultasi secara intensif sebagaimana disajikan dalam Gambar 1.

Tahap Preparasi: Brainstorming dan pembekalan pengetahuan dasar tentang pengembangan media multiliterasi berbasis engaged learning)

Tahap Inkubasi: Pengeraman ide dan pembuatan rancangan media pembelajaran

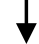

Tahap Iluminasi: Penuangan ide dalam bentuk desain media pembelajaran

Tahap Verifikasi: Evaluasi dan apresiasi terhadap media pembelajaran

Gambar 1. Bagan Metode Kegiatan
Gambar 1 mengilustrasikan metode kegiatan program ini secara bertahap. Tahap preparasi (persiapan) merupakan tahap penentuan topik yang akan dipelajari serta mengkoleksi kebutuhan yang harus disiapkan untuk mendukung pencapaian topik-topik yang sudah dipilih. Tahap ini diawali dengan pengumpulan data-data yang diperlukan yang dapat diakses dari berbagai sumber baik dalam online maupun offline. Penelusuran ini penting untuk memepoleh data yang benarbenar akurat yang dapat dikembangkan dan sesuai dengan topik-topik yang telah ditetapkan. Kegiatan ini dilakukan dengan beberapa cara: brainstorming antarguru dengan topiktopik yang telah dikoleksi sehingga hasilnya mendekati kebenaran secara konten (isi). Tahap inkubasi merupakan tahap pematangan dan pengolahan ide, atau sering juga disebut dengan "pengeraman ide". Dalam kaitan ini, guru dapat mencari inspirasi, merenungkan ide-ide, dengan disertai kreativitas dan inovasi. Setelah itu, guru membuat rancangan media pembelajaran secara berkelompok berdasarkan pengetahuan yang diperoleh dengan memadukan kreativitas, imajinasi, serta kontemplasi.

Tahap iluminasi merupakan tahap mengungkapkan ide atau pengekspresian. Tahap iluminasi ini diisi dengan mendesain secara lebih konkret dan detail atas rancangan yang dibuat dengan didampingi oleh tim. Pada proses ini, guru juga dapat memperkaya literasi dari media-media pembelajaran yang telah dikembangkan. Pada tahap ini, diharapkan guru mampu mengekplorasi segala sesuatu yang terkait dengan proses kreatif untuk menghasilkan media pembelajaran sesuai bidang matapelajarannya.

Tahap verifikasi merupakan tahap evaluasi media pembelajaran yang telah dikembangkan. Tahap ini dapat dikerjakan dengan cara membandingkan satu karya dengan karya lain, melalui kritik dan saran antar guru, demi kesempurnaan karya yang sedang dikembangkan. Setelah itu, dilakukan evaluasi media oleh narasumber dan guru. Kegiatan dirancang selama 1 kali tatap muka. Evaluasi dilakukan berdasarkan indikator yang mencakup beberapa hal, yaitu 1) orisinil dan sesuai dengan tujuan pembelajaran, (2) sesuai dengan 
karakteristik perkembangan peserta didik, (3) memanfaatkan berbagai sumber informasi, dan (4) menarik minat belajar siswa.

Dalam konteks ini, kemampuan guru untuk mengembangkan media menjadi penting agar pembelajaran menjadi lebih bermakna bagi siswa. Untuk kepentingan pengembangan media maka tahapan yang harus diikuti sesuai dengan metode yang telah dipilih. Selain itu, peserta mencermati rancaangan media pembelajaran multiliterasi berbasis engaged learning sebagaimana Tabel 1.

Berdasarkan Tabel 1, guru merancang media pembelajaran dengan terlebih dahulu mengidentifikasi kompetensi inti dan kompetensi dasar yang membutuhkan adanya media pembelajaran yang inovatif. Hal itu merujuk pada pengalaman pembelajaran sebelumnya yang bagi guru masih kurang tercapai target pembelajarannya sehingga media pembelajaran yang akan dibuat dapat mengatasi permasalahan tersebut. Selanjutnya, guru dapat memformulasikan indikator pembelajaran yang perlu dicapai siswa. Agar lebih jelas, guru menuliskan wujud media pembelajaran yang akan dibuat, yaitu audio, visual, atau audiovisual. Berkaitan dengan substansi inovasinya, guru mendesain aspek engaged learning dan aspek pembelajaran multiliterasi dalam media pembelajaran. Aspek engaged learning yang dikembangkan mengacu pada peningkatan keterampilan berpikir siswa (aspek pikiran), kepekaan emosional (aspek perasaan), dan kesadaran belajar mandiri (aspek motivasi intrinsik). Ketiga aspek tersebut dikembangkan dengan memanfaatkan metode yang dapat dipilih dalam engaged learning, seperti KWLT (know, want, learn, think), anticipation guide, color coding, sentence starter, dan sebagainya. Aspek pembelajaran multiliterasi yang dikembangkan dalam bentuk kegiatan literasi kritis dengan memanfaarkan beragam sumber belajar melalui proses pendalaman, pembandingan, analisis, hingga sintesis mendalam. Sebagai bentuk evaluasi pembelajaran, guru pun merancang wujud kegiatan lanjutan untuk mengukur pemahaman dan kompetensi siswa. Desain media pembelajaran tersebut diwujudkan secara konseptual dalam bentuk storyboard dengan memberikan deskripsi visual, deskripsi audio, dan deskripsi tekstual media pembelajaran.

Dengan demikian, hasil dan pembahasan dari kuesioner pretest dan postest dalam tahap evaluasi diolah dan disajikan dalam presentase yang dilengkapi dengan bentuk uraian secara deskriptif sehingga kesimpulan yang dibuat menjadi lebih komprehensif.

Tabel 1. Format Rancangan Media Pembelajaran Multiliterasi Berbasis Engaged Learning

\begin{tabular}{cll}
\hline No & Aspek & Keterangan \\
\hline A & Kelas/Semester & $:$ \\
B & Kompetensi Inti & $:$ \\
C & Kompetensi Dasar & $:$ \\
D & Indikator Pembelajaran & $:$ \\
E & Wujud Media Pembelajaran & $:$ (audio/visual/audiovisual) \\
F & Aspek Engaged Learning yang Dikembangkan & $:$ \\
& Aspek Pikiran & $:$ \\
& Aspek Perasaan & $:$ \\
& Aspek Motivasi Intrinsik & $:$ \\
& Metode pembelajaran dalam engaged learning yang digunakan & $:$ \\
G & Aspek Pembelajaran Multiliterasi yang Dikembangkan & \\
& Literasi Kritis & $:$ \\
& Keberagaman Sumber Belajar & $:$ \\
H & Kegiatan Lanjutan & $:$ (penugasan/resume/dll) \\
I & Storyboard Media Pembelajaran & $:$ \\
\hline
\end{tabular}




\section{HASIL DAN PEMBAHASAN}

Hasil dan pembahasan dijelaskan berdasarkan tahapan kegiatan pelatihan yang telah dilaksanakan sebagai berikut.

\section{Tahap Preparasi: Persiapan Pengembangan Media Pembelajaran}

Preparasi (persiapan) dilakukan dengan aktivasi prior knowledge para guru tentang media pembelajaran, pembelajaran multiliterasi, dan model engaged learning. Hal itu dilakukan untuk menggali informasi tentang pemahaman para guru tentang konsep dasar pengembangan media dalam media pembelajaran multiliterasi yang memanfaatkan engaged learning. Selain itu, juga untuk mengidentifikasi pengalaman para guru dalam mengembangkan media pembelajaran sebelum pelatihan ini dilaksanakan. Hal itu dilakukan dengan menyebarkan kuesioner melalui Google Form yang diisi oleh para guru yang mengikuti kegiatan pelatihan ini.

Berdasarkan hasil pengisian kuesioner, $50 \%$ dari total 12 guru menyatakan bahwa pelatihan pengembangan media pembelajaran sangat penting dilakukan, 41,7\% menyatakan penting, dan $8,3 \%$ menyatakan cukup penting. Para guru seluruhnya menyatakan pernah membuat media pembelajaran sendiri kemudian diterapkan dalam pembelajaran. Berkaitan dengan pembelajaran multiliterasi, didapatkan informasi bahwa di SMP Aisyiyah Boarding School Malang (ABSM) 25\% guru menyatakan bahwa pembelajaran multiliterasi sangat penting, 58,3\% guru menyatakan penting, dna $16,7 \%$ menyatakan cukup penting. Pembelajaran multiliterasi telah dilaksanakan di SMP ABSM melalui Gerakan Literasi Sekolah. Akan tetapi, terdapat kendala-kendala yang dialami para guru selama mengembangkan media pembelajaran, yaitu kurang maksimalnya media pembelajaran yang dikembangkan, kesulitan ide pengembangan media pembelajaran, pengaplikasian media pembelajaran di kelas tidak sesuai dengan tujuan yang diharapkan, dan keterbatasan waktu pengerjaan. Berdasarkan hal itu, para guru berharap dalam pelatihan ini agar mendapatkan ilmu dan mengembangan potensi dalam pengembangan media pembelajaran yang sesuai dengan materi sehingga dapat diterapkan dalam pembelajaran daring ini.

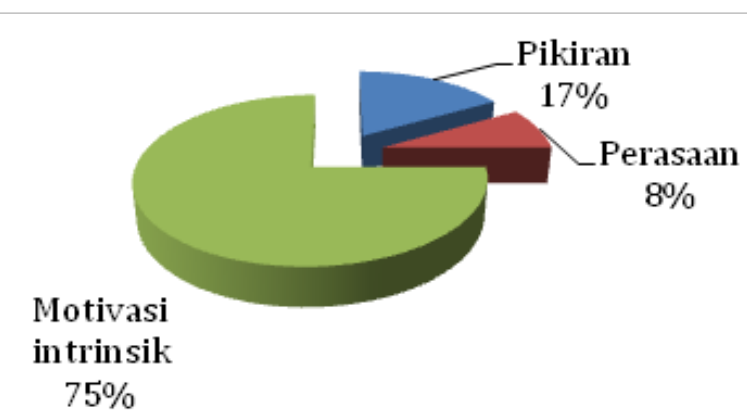

Gambar 2. Aspek Paling Penting dalam Pembelajaran Berdasarkan Engaged Learning

Berkaitan dengan engaged learning, didapatkan hasil bahwa 75\% guru berpandangan bahwa aspek paling penting dalam pembelajaran adalah motivasi intrinsik lalu baru aspek pikiran dan perasaan. Hal itu menunjukkan bahwa sebagian besar guru perlu mengembangkan media pembelajaran yang mampu meningkatkan motivasi dan minat belajar siswa. Dengan demikian, pelatihan ini menjadi penting dalam membantu para guru mengembangkan media pembelajaran multiliterasi berbasis engaged learning karena memanfaatkan beragam bentuk dan sumber belajar yang bervariasi serta mengakomodasi aspek pikiran, perasaan, dan motivasi intrinsik secara holistik. Hasil kuesioner tersebut disajikan pada Gambar 2 .

Setelah mendapatkan hasil kuesioner dari para guru, tim pelaksana melaksanakan brainstorming dengan tentang media-media pembelajaran yang sudah pernah digunakan. Brainstorming dilakukan satu kali tatap muka secara daring dengan menggunakan Google Meet, yakni pada 28 Juli 2020. Seluruh guru hadir dengan didampingi oleh Kepala Sekolah SMP ABSM sebagaimana Gambar 3.

Pada Gambar 3, para guru saling berdiskusi terkait dengan materi bahasa Indonesia dan mata pelajaran lainnya juga. Guru juga melakukan tanya jawab dengan tim pelaksana terkait media-media pembelajaran yang sudah dan akan dikembankgkan dalam pelatihan ini. Pada kegiatan preparasi ini pula, kontrak pelatihan disampaikan pada kepala sekolah dan para guru tentang hak yang diterima dan kewajiban yang perlu dilaksanakan selama kegiatan pelatihan dilaksanakan. 


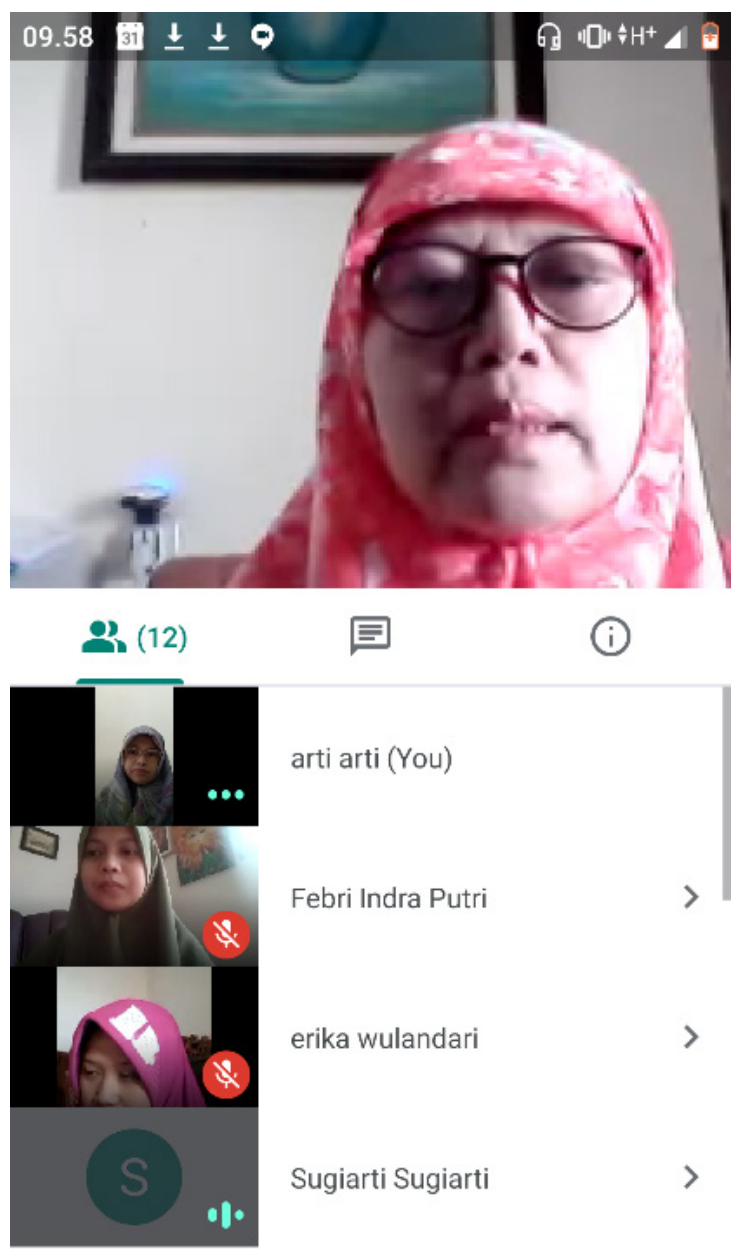

Gambar 3. Pertemuan Daring Tahap Preparasi

\section{Tahap Inkubasi: Pematangan Ide dalam Perancangan Pengembangan Media Pembelajaran Multiliterasi Berbasis Engaged Learning}

Tahap pematangan dan pengolahan ide, atau sering juga disebut dengan "pengeraman ide". Dalam kaitan ini, guru dapat mencari inspirasi, merenungkan ide-ide, dengan disertai kreativitas dan inovasi. Setelah itu, guru membuat rancangan media pembelajaran secara individu berdasarkan pengetahuan yang diperoleh dengan memadukan kreativitas, imajinasi, serta kontemplasi.

Pada kegiatan ini, para peserta menyusun rencana pengembangan media pembelajarannya secara detail sehingga bermanfaat dalam pengembangan media pada tahap selanjutnya. Pada format tersebut, engaged learning diimplementasikan dengan pengembangan aspek pikiran, perasaan, dan motivasi intrinsik karena ketiga aspek tersebut merupakan fokus penting yang perlu ditingkatkan secara holistik. Selain itu, pemanfaatan metode pembelajaran dalam engaged learning juga dilakukan, misalnya dengan memanfaatkan metode sentence starter, KWLT (know, want, learn, think), dan color coding. Tujuannya adalah agar implementasi engaged learning tersebut tidak hanya bersifat teknis, tetapi juga substantif.

Selain itu, implementasi pembelajaran multiliterasi dilakukan melalui kegiatan literasi kritis dan keberagaman sumber belajar. Hal itu diharapkan dapat menstimulus siswa untuk meningkatkan keterampilannya mengolah informasi dari beragam sumber untuk mendapatkan wawasan dan pengetahuan yang komprehensif dan berimbang. Melalui proses itu, siswa juga melakukan literasi kritis karena perlu menyeleksi, menganalisis, serta membandingkan beragam informasi yang didapatkan dari berbagai sumber belajar tersebut.

Pada tahapini, para peserta menyiapkan RPP sebagai rancangan kegiatan pembelajaran sesuai dengan media pembelajaran yang dikembangkan. Kegiatan dilanjutkan dengan menyusun rancangan sesuai format bagan 1 di atas. Selanjutnya, peserta menyampaikannya dalam forum diskusi secara daring agar mendapatkan masukan dan saran dari tim pendamping. Hal itu dijadikan sebagai bahan evaluasi dan rencana tindak lanjut pengembangan medianya. Selain RPP, para peserta juga membuat rancangan video pembelajaran berdasarkan format yang diberikan tim pelaksana sebagaimana disajikan pada tabel 1 . Tujuannya adalah para peserta dapat secara terstruktur merencanakan dan mendesain media pembelajaran sehingga pembelajaran multiliterasi dan engaged learning mampu diintegrasikan dalam media pembelajaran yang dikembangkan. Hal itu didasarkan pada pertimbangan bahwa pembelajaran sebaiknya tidak hanya dirancang dengan membuat desainnya saja, tetapi juga disusun dengan memperhatikan strategi pelaksanaan pembelajarannya (Bigatel \& EdelMalizia, 2018).

Gambar 4 berikut merupakan salah satu dokumentasi kegiatan pelatihan pada saat membahas rancangan video pembelajaran para peserta pelatihan. 

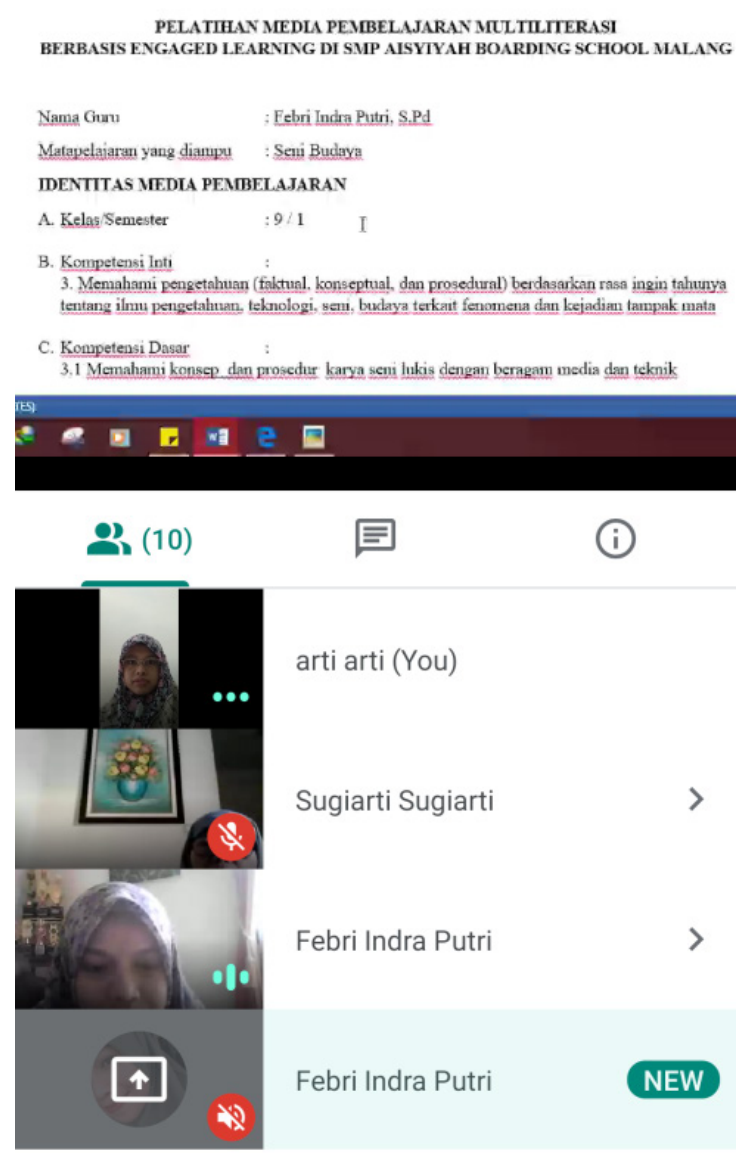

Gambar 4. Pertemuan Daring Tahap Inkubasi

Gambar 4 merupakan kegiatan pembahasan rancangan media pembelajaran multiliterasi berbasis engaged learning. Pada umumnya, para guru telah mampu merancang media pembelajaran secara terstruktur dan inovatif. Akan tetapi, perlu ada beberapa masukan terkait integrasi engaged learning dan penajaman pembelajaran multiliterasi.

\section{Tahap Iluminasi: Proses Pengembangan Media Pembelajaran Multiliterasi Berbasis Engaged Learning}

Pada tahap mengungkapkan ide atau pengekspresian. Tahap ini diisi dengan mendesain secara lebih konkret dan detail atas rancangan yang dibuat dengan didampingi oleh tim. Pada prosesini, guru juga dapat memperkaya literasi dari media-media pembelajaran yang telah dikembangkan. Pada tahap ini, diharapkan guru mampu mengeksplorasi segala sesuatu yang terkait dengan proses kreatif untuk menghasilkan media pembelajaran sesuai bidang mata pelajarannya. Peserta merealisasikan ide dari rancangan media pembelajaran yang sudah dibuat dalam bentuk video pembelajaran. Aspek pembelajaran multiliterasi direalisasikan dengan memanfaatkan beragam sumber belajar sehingga tidak hanya menyajikan teks, tetapi juga gambar, bagan, ilustrasi, peta konsep, audio, dan video. Selain itu, video yang dibuat juga mengandung unsur literasi kritis karena pada video tersebut para guru mengajak siswa untuk mencermati suatu hal untuk dikritisi dan ditelaah lebih dalam. Kegiatan tersebut dilanjutkan pada Lembar Kerja Peserta Didik (LKPD) yang dikerjakan siswa secara mandiri untuk selanjutnya dipantau dan dibimbing oleh guru. Hal itu sesuai dengan penelitian sebelumnya yang menyatakan bahwa keterampilan berpikir kritis tidak hanya berkaitan dengan kegiatan berpikir, tetapi juga berkenaan dengan kegiatan mengevaluasi, merasakan, menentukan, dan menempatkan informasi berdasarkan konteksnya (Fried, 2013).

Pada tahap ini, para peserta menghasilkan video pembelajaran berdurasi 10-20 menit. Terdapat beragam software yang digunakan untuk membuat video, seperti Kinemaster, Filmora, Powtoon, dan Screen Recorder. Video yang dibuat menampilkan materi-materi yang disajikan dan divisualisasikan secara menarik dan disertai rekaman audio atau audio visual yang menampilkan guru sedang menjelaskan materi yang disajikan. Dengan demikian, dengan video tersebut, siswa tidak hanya membaca materi yang disajikan, tetapi juga mengamati dan menyimak penjelasan guru.

Pada tahap ini, rata-rata semua guru mampu menghasilkan video pembelajaran yang menarik. Implementasi engaged learning tampak dari kegiatan pembelajaran yang memicu peningkatan aspek pikiran, perasaan, dan motivasi intrinsik siswa, misalnya melalui kegiatan mengamati video yang disajikan. Selain itu, metode dalam engaged learning juga digunakan, misalnya siswa diminta melanjutkan sentence starter pada awal video agar dapat dilakukan aktivasi prior knowledge. Contohnya pada sentence starter yang berbunyi "Hal yang sudah saya ketahui tentang teks laporan hasil observasi adalah ...," siswa dapat melanjutkannya dengan prior knowledge atau pengetahuan awal 
yang dimilikinya. Berdasarkan pengalaman para guru peserta pelatihan ini, pemanfaatan metode pembelajaran dalam engaged learning mampu memfasilitasi pemahaman konsep materi secara lebih komprehensif. Hal itu sesuai dengan penelitian sebelumnya yang menyatakan bahwa metode-metode dalam engaged learning banyak dimanfaatkan untuk mengatasi permasalahan kurangnya pengetahuan konseptual yang mendalam (De Jong, 2019).

Selain pembelajaran multiliterasi dan engaged learning yang diintegasikan dalam media pembelajaran yang dikembangkan, nilainilai keislaman turut dimasukkan dalam video. Misalnya, dengan mencantumkan ayat suci Al-Qur'an atau Hadis yang berkaitan dengan materi yang dibahas. Hal itu menjadi penciri khusus video pembelajaran yang dikembangkan para peserta dibandingkan dengan media pembelajaran lainnya.

Dengan demikian, media pembelajaran yang dihasilkan dapat memfasilitasi pembelajaran yang bermakna. Engaged learning dapat diimplementasikan dengan melaksanakan pembelajaran yang mampu membuat siswa mengalami pembelajaran yang bermakna. Hal itu dapat dilakukan melalui proses modifikasi dan elaborasi materi melalui berbagai kegiatan: interpretasi, pemberian contoh, klasifikasi, inferensi, diferensiasi, dan pengorganisasian informasi yang kemudian dapat direfleksikan secara mandiri atau berkelompok (Prince, 2004).

Gambar 5 adalah tangkapan layar tampilan video pembelajaran yang dihasilkan para peserta pelatihan.

Gambar 5 merupakan media pembelajaran bahasa Indonesia hasil karya peserta pelatihan. Materi yang dijelaskan adalah teks laporan hasil observasi. Tampilan visual menarik karena menyajikan teks materi disertai video guru yang sedang menjelaskan. Guru juga memanfaatkan beragam sumber belajar untuk meningkatkan pembelajaran multiliterasi, yakni dengan menampilkan video, teks berita, dan gambar pendukung untuk melatih siswa dalam melakukan observasi. Beragam sumber belajar tersebut juga memunculkan motivasi intrinsik siswa untuk mengembangkan keterampilan berpikir dan kepekaan emosi sebagai bentuk penerapan engaged learning.

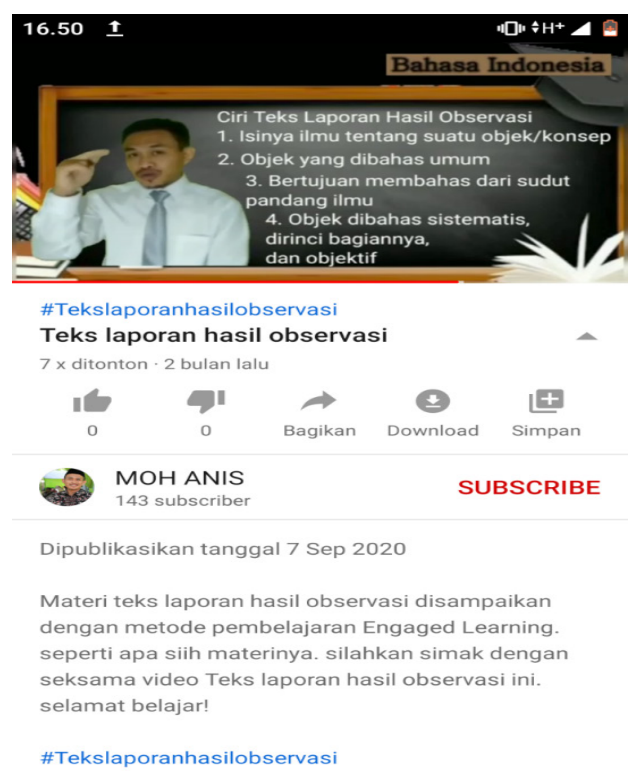

Gambar 5. Video Pembelajaran Peserta Pelatihan yang Diunggah di Youtube

Tahap Verifikasi: Evaluasi Pengembangan Media Pembelajaran Multiliterasi Berbasis Engaged Learning

Selanjutnya, kegiatan evaluasi media pembelajaran dilakukan dengan cara memberikan masukan dan saran demi kesempurnaanvideoyangsedangdikembangkan. Hal ini, dilakukan oleh tim pelaksana dan guru untuk saling melakukan memberi saran untuk perbaikan. Kegiatan dilaksanakan melalui tatap muka secara daring. Evaluasi dilakukan berdasarkan indikator yang mencakup beberapa hal, yaitu 1) orisinalitas dan kesesuaian dengan tujuan pembelajaran, (2) kesesuaian dengan karakteristik perkembangan peserta didik, (3) pemanfaatan berbagai sumber informasi, dan (4) kemampuan menarik minat belajar siswa.

Pada tahap ini, para peserta menampilkan video yang sudah dikembangkan. Selanjutnya, tim pelaksana memberikan masukan dan saran pada setiap peserta pelatihan. Para peserta juga saling memberikan masukan. Hal itu digunakan sebagai bahan perbaikan agar video pembelajaran bisa lebih bagus lagi dari segi isi, bahasa, dan tampilan penyajiannya. Setelah video pembelajaran direvisi berdasarkan masukanmasukan tersebut, para peserta mengunggah video tersebut ke dalam channel Youtube masing-masing sehingga dapat dipergunakan dan bermanfaat bagi masyarakat luas. 
Tabel 1. Hasil Pengembangan Media Pembelajaran Multiliterasi Berbasis Engaged Learning

\begin{tabular}{|c|c|c|c|c|c|c|c|}
\hline \multirow[b]{2}{*}{$\begin{array}{l}\text { Kode } \\
\text { Peserta }\end{array}$} & \multicolumn{5}{|c|}{ Aspek Pengembangan Media Pembelajaran } & \multicolumn{2}{|c|}{ Skor } \\
\hline & $\begin{array}{l}\text { Penentuan } \\
\text { Topik } \\
\text { (Preparasi) }\end{array}$ & $\begin{array}{c}\text { Pematangan } \\
\text { Gagasan } \\
\text { (Inkubasi) }\end{array}$ & $\begin{array}{l}\text { Mendesain } \\
\text { Rancangan } \\
\text { (Iluminasi) }\end{array}$ & $\begin{array}{c}\text { Evaluasi } \\
\text { Media } \\
\text { (Verifikasi) }\end{array}$ & $\begin{array}{c}\text { Refleksi } \\
\text { Kegiatan }\end{array}$ & Pretest & Postest \\
\hline P1 & SB & SS, KWLT, CC & $\mathrm{B}$ & SB & SB & 75 & 80 \\
\hline $\mathrm{P} 2$ & $\mathrm{~B}$ & SS, KWLT & $\mathrm{B}$ & $\mathrm{B}$ & SB & 65 & 75 \\
\hline P3 & SB & SS, KWLT, CC & SB & SB & SB & 70 & 85 \\
\hline $\mathrm{P} 4$ & $\mathrm{~B}$ & SS, KWLT, CC & SB & $\mathrm{B}$ & SB & 75 & 75 \\
\hline P5 & SB & SS, KWLT, CC & SB & SB & SB & 70 & 85 \\
\hline P6 & SB & SS, KWLT, CC & $\mathrm{B}$ & SB & SB & 70 & 80 \\
\hline $\mathrm{P} 7$ & B & SS, KWLT & $\mathrm{B}$ & $\mathrm{B}$ & SB & 65 & 75 \\
\hline P8 & SB & SS, KWLT, CC & SB & SB & SB & 70 & 85 \\
\hline P9 & SB & SS, KWLT, CC & SB & SB & SB & 70 & 85 \\
\hline P10 & B & SS, KWLT & SB & B & B & 65 & 75 \\
\hline P11 & B & SS, KWLT, CC & SB & SB & $\mathrm{B}$ & 65 & 80 \\
\hline $\mathrm{P} 12$ & SB & SS, KWLT, CC & SB & SB & SB & 80 & 85 \\
\hline \multicolumn{6}{|c|}{ Jumlah } & 840 & 965 \\
\hline
\end{tabular}

Sumber: Data Diolah 2020

Berdasarkan Tabel 1, terjadi peningkatan pretest dan postest peserta pelatihan sebesar $14 \%$. Pada pretest, hanya $25 \%$ yang skornya minimal 75 , tetapi pada postest meningkat menjadi $100 \%$. Secara bertahap, semakin banyak peserta pelatihan yang melaksanakan kegiatan dengan Sangat Baik (SB) mulai dari tahap preparasi, inkubasi, iluminasi, hingga verifikasi. Para peserta memiliki motivasi instrinsik yang tinggi dengan memadukan aspek pikiran dan perasaan secara memadai. Dalam pematangan gagasan peserta memanfaatkan metode Sentence Starter (SS) serta KWLT (Know, Want, Learn, Think), dan Color Coding (CC). Tujuannya adalah agar implementasi engaged learning tersebut tidak hanya bersifat teknis, tetapi juga substantif. Selain itu, dalam mendesain rancangan dengan memanfaatkan berbagai sumber belajar pembelajaran multiliterasi direalisasikan dengan memanfaatkan beragam sumber belajar sehingga tidak hanya menyajikan teks, tetapi juga gambar, bagan, ilustrasi, peta konsep, audio, dan video. Selain itu, video yang dibuat juga mengandung unsur literasi kritis karena pada video tersebut para guru mengajak siswa untuk mencermati suatu hal untuk dikritisi dan ditelaah lebih dalam. Berdasarkan hal itu, pembelajaran yang dirancang didesain untuk dapat berkontribusi dalam pengembangan aspek pikiran, perasaan, dan motivasi intrinsik. Sebagaimana dikemukakan penelitian sebelumnya, bahwa engaged learning mampu memfasilitasi peningkatan aspek kognitif, afektif, dan psikomotorik dengan motivasi intrinsik yang mendukung kegiatan pembelajaran yang kreatif dan kritis (Sugiarti \& Prihatini, 2019). Selain itu, model multiliterasi kritis mampu melibatkan siswa untuk aktif dalam mengajukan pertanyaan atau membuat kesimpulan sendiri. Melalui pembelajaran multiliterasi yang menantang, siswa mampu memiliki rasa percaya diri, cerdas, komunikatif, berani, dan berkarakter (Rahman \& Damaianti, 2019).

Dalam kegiatan evaluasi media peserta menyatakan bahwa video menarik dan inspriratif sehingga dapat memacu peserta didik untuk belajar lebih baik. Dari sisi, respon peserta mayoritas kegiatan ini dengan bagus untuk melatih guru melakukan inovasi pembelajaran. Kemudian hasil refleksi dari keseluruhan kegiatan peserta mayoritas menyampaikan bahwa kegiatan pelatihan ini sangat bermanfaat bagi guru mengingat tuntutan kompetensi 
berkelanjutan salah satunya adalah kreativitas guru dalam membuat video pembelajaran.

Di sisi lain, para peserta juga melakukan refleksi terhadap proses pelatihan yang sudah dilakukan. Hal itu dimaksudkan agar diketahui kelebihan dan kekurangan selama proses pelatihan agar pada penyelenggaraan selanjutnya dapat dilaksanakan lebih baik lagi. Oleh karena itu, tim pelaksana memberikan angket yang perlu diisi oleh seluruh peserta pelatihan. Berdasarkan pengisian angket, didapatkan hasil bahwa $70 \%$ peserta menyatakan kegiatan pelatihan ini sangat bermanfaat dan 30\% menyatakan bermanfaat. Sebanyak 50\% guru telah memanfaatkan video pembelajaran yang dibuat pada penelitian ini untuk pembelajaran secara daring, sedangkan 50\% guru berencana akan melaksanakan video untuk pembelajaran yang akan datang karena menunggu jadwal pelaksanaannya. Para guru juga menyampaikan harapannya agar kegiatan pelatihan serupa dapat dilaksanakan pada waktu mendatang dengan memanfaatkan strategi dan model pembelajaran serta pengembangan perangkat pembelajaran lainnya.

\section{KESIMPULAN}

Berdasarkan uraian tersebut, dapat disimpulkan bahwa kegiatan pelatihan pengembangan media pembelajaran dilaksanakan sesuai target yang direncanakan. terjadi peningkatan pretest dan postest peserta pelatihan sebesar $14 \%$. Pada pretest, hanya $25 \%$ yang skornya minimal 75 , tetapi pada postest meningkat menjadi 100\%. Secara bertahap, semakin banyak peserta pelatihan yang melaksanakan kegiatan dengan Sangat Baik (SB) mulai dari tahap preparasi, inkubasi, iluminasi, hingga verifikasi.

$\begin{array}{ccc}\text { Persiapan } & \text { kegiatan } & \begin{array}{r}\text { dilaksanakan } \\ \text { dengan menggali }\end{array} \text { prior } \\ \text { penowledge dan } \\ \text { pengalaman guru dalam } & \text { mengembangkan }\end{array}$

media pembelajaran dan dengan kegiatan brainstorming. Selanjutnya, pematangan ide dalam perancangan pengembangan media pembelajaran multiliterasi berbasis engaged learning dilakukan dengan memanfaatkan kegiatan literasi kritis dan keberagaman sumber belajar. Hal itu diharapkan dapat menstimulus siswa untuk meningkatkan keterampilannya mengolah informasi dari beragam sumber untuk mendapatkan wawasan dan pengetahuan yang komprehensif dan berimbang

Pada proses pengembangan media pembelajaran multiliterasi berbasis engaged learning, Pembelajaran multiliterasi mampu diimplementasikan dalam media pembelajaran yang dikembangkan melalui pemanfaatan beragam sumber belajar dan stimulasi literasi kritis. Engaged learning diimplementasikan melalui pemanfaatan metode dalam engaged learning dan pengembangan aktivitas yang mampu meningkatkan aspek pikiran, perasaan, dan motivasi intrinsik. Selain itu, para peserta juga memasukkan nilai-nilai keislaman dalam media pembelajaran sebagai penciri khusus lembaga pendidikannya yang juga berbasis pesantren, yakni dengan memasukkan kutipan ayat suci Al-Qur'an atau Hadis yang berhubungan dengan materi yang disampaikan.Media pembelajaran yang telah dikembangkan para guru dipresentasikan dan diberi evaluasi berupa masukan dan saran yang berkaitan dengan hasil pengembangan media.

\section{PERSANTUNAN}

Ucapan terima kasih kami sampaikan kepada Direktorat Penelitian dan Pengabdian kepada Masyarakat (LPPM) Universitas Muhammadiyah Malang yang telah memberikan pendanaan pada program ini sehingga kegiatan dapat berjalan dengan baik dan lain. Selain itu, terima kasih juga kami sampaikan kepada kepala sekolah serta para guru SMP Aisyiyah Boarding School Malang yang telah berpartisipasi aktif dalam kegiatan ini.

\section{REFERENSI}

Al Mubarok, M. S. (2019). Pengembangan Media Pembelajaran Macromedia Flash berbasis Web pada Materi Bangun Ruang Sisi Lengkung Kelas IX SMPN 1 Brangsong. Universitas Islam Negeri Walisongo. 
Banna, J., Lin, M. F. G., Stewart, M., \& Fialkowski, M. K. (2015). Interaction Matters: Strategies to Promote Engaged Learning in An Online Introductory Nutrition Course. Journal of Online Learning and Teaching/MERLOT, 11(2), 249. https://www.ncbi.nlm.nih.gov/pmc/articles/PMC4948751/

Barkley, E. (2010). Student Engagement Techniques. Jossey-Bass.

Cahyani, P. I. (2018). Pengaruh Penggunaan Media Pembelajaran Microsoft Power Point terhadap Minat Belajar Matematika Siswa Kelas VIII SMP Swasta Ar-Rahim Percut Tahun 2018. Universitas Islan Negeri Sumatera Utara.

Cooper, N., Lockyer, L., \& Brown, I. (2013). Developing Multiliteracies in A Technology-Mediated Environment. Educational Media International, 50(2), 93-107. https://doi.org/10.1080/09523 987.2013.795350

Cope, B., \& Kalantzis, M. (2013). “Multiliteracies”: New Literacies, New Learning. In Framing Languages and Literacies. Routledge.

Dafit, F., Mustika, D., \& Ain, S. Q. (2018). Efektivitas Pembelajaran Multiliterasi terhadap Kemampuan Berpikir Kritis Siswa Sekolah Dasar pada Materi Ekosistem. JMIE: Journal of Madrasah Ibtidaiyah Education, 2(2), 181-193. http://dx.doi.org/ 10.32934/jmie.v2i2.71

Daniel, B. (2015). Big Data and Analytics in Higher Education: Opportunities and Challenges. British Journal of Educational Technology, 46(5), 904-920. https://doi.org/10.1111/bjet.12230

De Jong, T. (2019). Moving Towards Engaged Learning in STEM Domains; There Is no Simple Answer, But Clearly A Road Ahead. Journal of Computer Assisted Learning, 35(2), 153-167.

Dean, K. L., \& Wright, S. (2017). Embedding Engaged Learning in High Enrollmentlecture-Based Classes. Higher Education, 74(4), 651-668. https://doi.org/10.1007/s10734-016-0070-4

Fried, J. (2013). Engaged Learning: Why Feelings Matter. About Campus: Enriching the Student Learning Experience, 18(1), 2-8. https://doi.org/10.1002/abc.21105

Kusumaningtyas, R., Sholehah, I. M., \& Kholifah, N. (2020). Peningkatan Kualitas Pembelajaran Guru melalui Model dan Media Pembelajaran Bagi Generasi Z. Warta LPM, 23(1), 54-62. https://doi. org/10.23917/warta.v23i1.9106

Mirra, N., Morrell, E., \& Filipiak, D. (2018). From Digital Consumption to Digital Invention: Toward a New Critical Theory and Practice of Multiliteracies. Theory into Practice, 57(1), 12-19. https:// doi.org/10.1080/00405841.2017.1390336

Muhson, A. (2010). Pengembangan Media Pembelajaran Berbasis Teknologi Informasi. Jurnal Pendidikan Akuntansi Indonesia, 8(2), 1-10. https://doi.org/10.21831/jpai.v8i2.949

Prince, M. (2004). Does Active Learning Work? A Review of the Research. Journal of Engineering Education, 93(July), 223-231.

Rahman, F. A., \& Damaianti, V. S. (2019). Model Multiliterasi Kritis dalam Pembelajaran Siswa Sekolah Dasar. JPD: Jurnal Pendidikan Dasar, 10(1), 27-34.

Ramdhani, S., Maryam, S., \& Komala, E. (2021). The Life Map For Developing Multiliteracies Competence: A Preliminary Study. Proceedings International Conference on Education of Suryakancana, 1(February), 206-211.

Rifai, A. B., \& Setyaningsih, N. H. (2019). Keefektifan Model Multiliterasi Digital dan Model KreatifProduktif pada Pembelajaran Menulis Teks Cerita Fantasi. DWIJA CENDEKIA: Jurnal Riset Pedagogik, 3(1), 50-61.

Sari, E. S., Suryaman, M., \& Lestyarin, B. (2013). a Model of Multiliteracy in the Indonesian Language and. Litera, 17(2), 1-12. 
Prihatini dan Sugiarti - Implementasi Pembelajaran Multiliterasi Berbasis Engaged Learning ...

Sugiarti, S., \& Prihatini, A. (2019). Engaged Reading Strategy in Literature Appreciation Learning and Its Implications on Character Education. 1-10. https://doi.org/10.4108/eai.7-8-2019.2288407

Supriyono, H., Sujalwo, S., Sapoetra, A., \& Rahayu, E. T. (2015). Pelatihan Pengembangan Media Pembelajaran Berbasis Web Bagi Guru SMP dan SMA Muhammadiyah Kartasura. Warta LPM, 18(2), 98-109. https://doi.org/10.23917/warta.v18i2.1949

Susilo, S. V., \& Garnisya, G. R. (2018). Penerapan Model Multiliterasi untuk Meningkatkan Kemampuan Membaca Pemahaman Siswa Sekolah Dasar. Jurnal Cakrawala Pendas, 4(2), 66-71.

Van de Weghe, R. (2009). Engaged Learning. Corwin.

Wahyudin, D., Sudrajat, R. T., \& Mahardika, R. Y. (2020). Pengaruh Multiliterasi terhadap Perkembangan Minat Menulis di Kalangan Mahasiswa. Parole: Jurnal Pendidikan Bahasa Dan Sastra Indonesia, 3(6), 909-914.

Widodo, S., \& Wahyudin. (2018). Selection of Learning Media Mathematics for Junior School Students. Turkish Online Journal of Educational Technology - TOJET, 17(1), 154-160. 